DEPARTMENT OF THE INTERIOR

UNITED STATES GEOLOGICAL SURVEY

\title{
SURFICIAL GEOLOGIC MAP OF THE HAMPDEN QUADRANGLE, MASSACHUSETTS AND CONNECTICUT
}

\section{By Carol T. Hildreth and Roger B. Colton}

Prepared in cooperation with

THE COMMONWEALTH OF MASSACHUSETTS DEPARTMENT OF PUBLIC WORKS and

THE STATE OF CONNECTICUT GEOLOGICAL AND NATURAL HISTORY SURVEY 